\title{
African Yam Bean the Choice for Climate Change Resilience: Need for Conservation and Policy
}

\author{
C. V. Nnamani, D. B. Adewale, H. O. Oselebe, and C. J. Atkinson
}

\section{Contents}

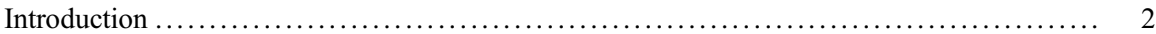

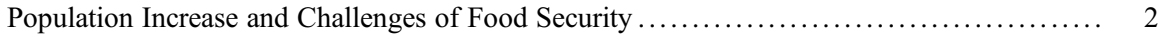

Proffering Solution with Neglected and Underutilized Plant Genetic Resources ............ 4

African Yam Bean an Underutilized Plant Genetic Resources ........................ 6

Nutritional Potentials of African Yam Bean for Climate Change Adaptation ............... 7

Nomenclatural Etymology of African Yam Bean to Climate Change .................... 9

African Yam Bean, the Choice for Climate Change Resilience ........................ 11

Policy and Conservation African Yam Bean ....................................... 13

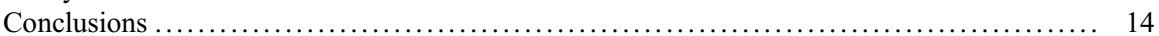

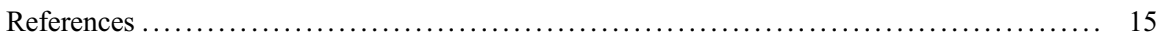

This chapter was previously published non-open access with exclusive rights reserved by the Publisher. It has been changed retrospectively to open access under a CC BY 4.0 license and the copyright holder is "The Author(s)". For further details, please see the license information at the end of the chapter.

C. V. Nnamani $(\square)$

Plant Systematics and Conservation Biology Research Unit, Department of Applied Biology,

Faculty of Science, Ebonyi State University, Abakaliki, Nigeria

e-mail: nnamanicatherine@ebsu.edu.ng

D. B. Adewale

Department of Crop Science and Horticulture, Federal University Oye-Ekiti, Ikole-Ekiti, Nigeria

H. O. Oselebe

Department of Crop Production \& Landscape Management, Ebonyi State University, Abakaliki, Nigeria

C. J. Atkinson

Natural Resources Institute, University of Greenwich, Chatham Maritime, UK

e-mail: c.j.atkinson@gre.ac.uk; c.j.atkinson@greenwich.ac.uk 


\section{Abstract}

Global warming has emerged as a major challenge to development and human wellbeing in Sub-Saharan Africa in general and Nigeria in particular. Periodic incidents show that this challenge will continue and increase in impact on all aspects of natural resources - agriculture, ecosystems services, biodiversity depletion, environmental degradation and human health. Recognizing the enormous potential of underutilized plant genetic resources (PGRs) is crucial as sources of solutions to a number of these threatening challenges emanating from climate change (food and nutrition insecurity, genetic erosion, loss of agro-biodiversity, green job growth and income generation) cannot be overemphasized. Sphenostylis stenocarpa (Hochst. ex. A. Rich) Harms., commonly known as African yam bean (AYB) belonging to the leguminous Fabaceae, is an underutilized PGR with rich portfolio which could serve as vital source of robust adaption and resilient germplasm for vulnerable local communities in Nigeria. Its substantial nutritional, environmental, cultural, social, medicinal, industrial and soil restorative potentials underpins its position as climate - smart species. Enhancing the potentials of African yam bean via robust innovative approaches for wider utilization through accelerated research, farmer seed exchanges, in-situ and ex-situ conservations, farmers selection, and policy programs such as seed sovereignty will accentuate its adaptation and used as resilient climate -smart species for the vulnerable groups in Nigeria to cushion impact of climate change.

\section{Keywords}

African yam bean - Climate smart species - Adaptation climate change Resilience $\cdot$ Conservation $\cdot$ Nigeria

\section{Introduction}

The Intergovernmental Panel on Climate Change (IPCC) reported that global warming of $1.5^{\circ} \mathrm{C}$ and greater upsurge of $2{ }^{\circ} \mathrm{C}$ is projected for $2046-2065$ and that these will have consequential impacts on food and water security, health, and other components of sustainable development, limiting strategies for adaptation, losses and damages to biodiversity and ecosystem services (IPCC 2018). All players are potential culprits to these increase, and accordingly need to undertake considerable behavioral changes to counteract this life threatening global warming, particularly in Sub-Saharan Africa. However, the above scenario is dependent on the level of anthropogenic activities on future greenhouse gas emissions (Pachauri and Meyer 2014).

Resilience is required within any systems to deal with climate stresses and disturbances and this include the willingness to change, skills to learn and capacity to adapt to such changes. It is therefore the zeal of managing changes and adaptations that can stand the test of current and future climate risks. 


\section{Population Increase and Challenges of Food Security}

There has been a geometric increase in global population over the last 200 years and it is projected to continue to rise. United Nations forecast stated that due to exponential growth, that population will rise from the current 7 billion to reach 9.7 billion by 2050 and subsequently 10.9 billion by 2100 (Fig. 1). This brings with it a number of life threatening challenges, especially in the absence of adequate food production technology, integrated programs which simultaneously address those community needs for food and reproductive health and impact of climate variability and change (World Bank 2014). The consequential effects of this population increase will be greater in Sub-Saharan Africa due to many factors such as, higher fertility rate, demographically younger population entering childbearing life phase, joblessness and a more volatile employment market.

Rapid national population growth has induced and intensified major environmental changes in response to climate change and variability which have led to the emergence of novel pests and diseases, loss of crop genetic diversity and a decline in resources such as water (Dobermann and Nelson 2013). Despite these, current global food production rates being at there highest level, they still fail to match population demand. Given the predicted population increase, food production will need to increase to meet demand by between 59\% and $98 \%$ by 2050 (Elferink and Schierhorn 2016). United Nations Food and Agriculture Organization (FAO 2010) estimated that about 795

\section{MOST POPULOUS COUNTRIES 2020-2100 (MILLIONS)}

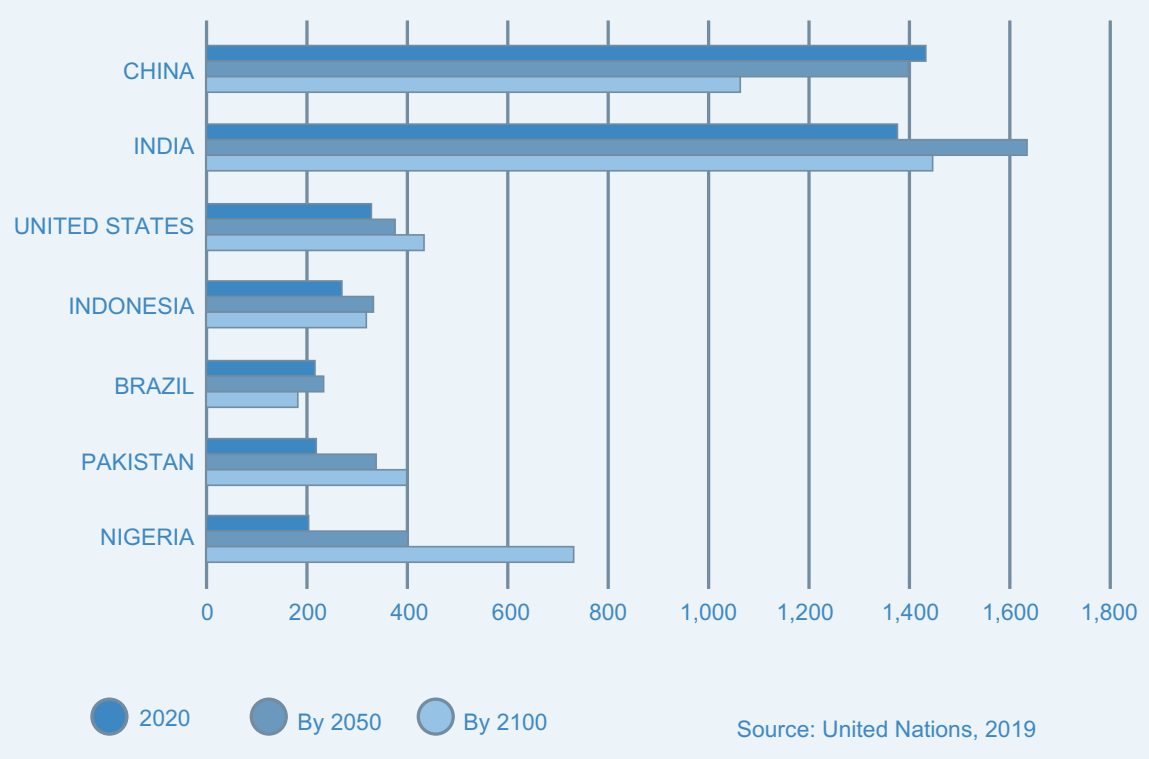

Fig. 1 Predicted population growth for 2020-2100 
million people, of the current 7.3 billion population, suffered chronic malnourishment between 2014 and 2018 and majority of these people lived in developing countries. The Global Hunger Index (Grebmer et al. 2019) shows that multiple countries have higher hunger levels now than in 2010, and approximately 45 countries in current reality will not be able to achieve lower levels of hunger by 2030 .

Poor monotonous diets, low in calorific quantity and quality with respect to nutritional level, variety and diversity are the primary cause for poor human health in many developing countries. Coincidentally, while the number of mouths to feed is increasing more rapidly than those farmers who are able to produce food. Hunger, malnutrition and famines and many endemic diseases, desertification, and floods continue to pose high risks in developing countries with low resilience which will be further exacerbated by climate change and climate variability aboard (Dobermann and Nelson 2013).

Nigeria ranks 93rd out of 117 qualifying countries with a score of 27.9, showing that its population is malnourished with high number of hungry people. This is an indication that out of the 162.5 million people, 1 in every 7 go to bed hungry (Grebmer et al. 2019). Mary Robinson, an Adjunct Professor of Climate Justice, Trinity College Dublin and former UN High Commissioner for Human Rights stated that "it is a terrible global indictment that after decades of sustained progress in reducing global hunger, climate change and conflict are now undermining food security in the world's most vulnerable regions." She concluded that with the number of hungry people rising from 785 million in 2015 to 822 million in 2018, "we can no longer afford to regard the 2030 Agenda and the Paris Climate Agreement as voluntary. This could be inferred from the level of changes over time in West Africa (Fig. 2). The above scenario needs vital actions and collective change of

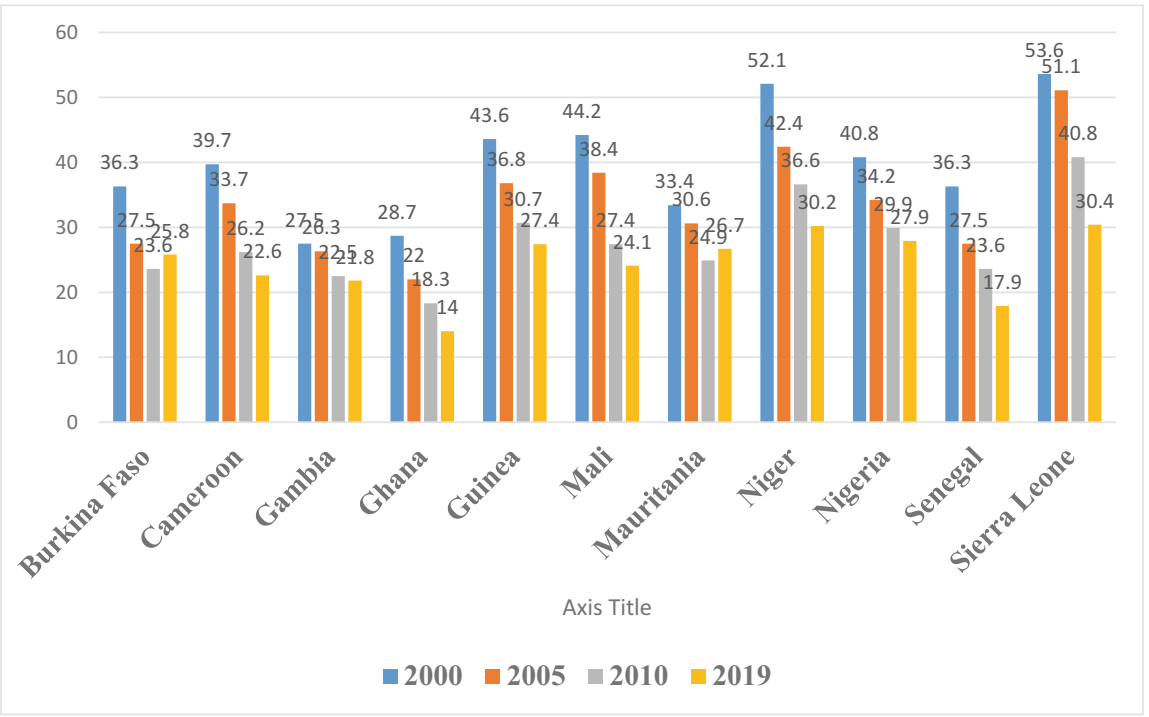

Fig. 2 West Africa Global Hunger Index scores, and changes over time. (Source: Grebmer et al. 2019) 
attitude at both global and local levels in order to secure a habitable world for our forthcoming generations" (Grebmer et al. 2019).

\section{Proffering Solution with Neglected and Underutilized Plant Genetic Resources}

Plant genetic resources (PGR) are those varieties of heritable materials confined in traditional selections and modern domesticated cultivars together with their wild relatives and other wild plant species locally used as food, feed for domestic animals, fibre, clothing, medicine, shelter, wood, timber, energy and for recreational activities.

Neglected and underutilized plant genetic resources are domesticated and wild plants species which have been used for centuries as sources of food, fibre, fodder, oil, or have medicinal properties (stimulants, narcotics, aromatics), but their importance has remained unharnessed, abandoned, replaced with exotic foods or only very slowly now being considered for use. They are known by various names, including orphan, abandoned, lost, forgotten, neglected, underutilized, local, minor, poor man's food, traditional, alternative, niche, or underdeveloped plants (Padulosi 2017). Their underutilized potentials can be significantly exploited to combat climate change, as a future "smart crop" to improve food and nutrient insecurity. Here we adopt a progressive and positive approach to their potential exploitation as a source of "smart food," with an emphasis on their exploitation and/or development into viable future crops which are climate resilient. The Global Facilitation Unit for Underutilized Species (Bhat and Taiwo 2015) defines these species, as those with a potential not fully exploited; with respect to contributing to food security and poverty alleviation, combined with their strong links to local community cultural heritage. Their limited or poor documentation by research are evidenced by their adaptation to specific agroecological niches, a weak or non-existent seed supply systems, fully in the domains of traditional users only. They are produced with little, or no external inputs.

Our ancestors used over 7000 plant genetic resources (PGRs) as food, from which farmers produced about $70 \%$ of the global food supply (Bhat and Taiwo 2015). Currently, very few of these PGRs are still exploited in sustaining humans. Making food and nutrient security dependent on a handful of crops with $65 \%$ requirements for protein, calories and minerals met by wheat, rice, yam and cassava (FAO 2017). This shrinking portfolio of PGRs, shifts in life style, and the preference for fast foods are currently contributing factors involved in food and nutrient insecurity. These are reducing the capacity of farmers to adapt to changing markets, to innovate, to develop supply chains, and our ability to cope with climate change variability and its extremities (IPGRI 2003). Recognizing the considerable potentials which underutilized PGR can provide is crucial in finding solutions to the impacts of climate change on food and nutritional insecurity, genetic erosion, conservation of agro-biodiversity, green growth jobs and income generation (Padulosi et al. 2013; Nnamani 2015).

Nigeria as a nation holds a rich variety of PGRs linked to food, and other treasured traits. However, most of these species have received little, or no attention with respect to support for basic research, breeding improvement, commercial exploitation of germplasm selections, or consideration by policy itineraries to 
support enhanced utilization, thereby leaving them neglected. In order to meet food security challenges for a growing population under changing climate, it is necessary to identify and valorize these neglected and underutilized species (NUS) to develop greater resilience within local communities and the adaptation potential to increasing climate unpredictability and change.

\section{African Yam Bean an Underutilized Plant Genetic Resources}

Sphenostylis stenocarpa (Hochst. ex. A. Rich) Harms, customarily called African yam bean (AYB), is a legume of the subfamily Faboideae and family Fabaceae. Sphenostylis as a genus is represented by only 7 species (Potter and Doyle 1992). African yam bean is an orphan crop cultivated and utilized by local communities. It is a climbing annual, prostrate, or erect and approximately 1-3 $\mathrm{m}$ tall. The leaves are trifoliate, about $2.7-13 \mathrm{~cm}$ long and $0.2-5.5 \mathrm{~cm}$ broad. The inflorescence could be a raceme which shows an acropetal variety of flowering with pink colour intermingled with purple, twisted backward characteristics of the Fabaceae family (Fig. 3).

African Yam Bean is synonymous with African continent only, its geographical distribution is tolerated mainly within the soil, climate, and vegetation of Africa especially within the range of latitudes $15^{\circ}$ North to $15^{\circ}$ South and longitudes $15^{\circ}$ West to $40^{\circ}$ East (Adewale et al. 2008). The above geographical range could be referred to as the center of diversity of AYB (Fig. 3) since there is no record of the origin of the crop in any other continent beyond Africa (Potter and Doyle 1992). It is a crop of African origin, made for Africans and utilized as such in Africa, hence this

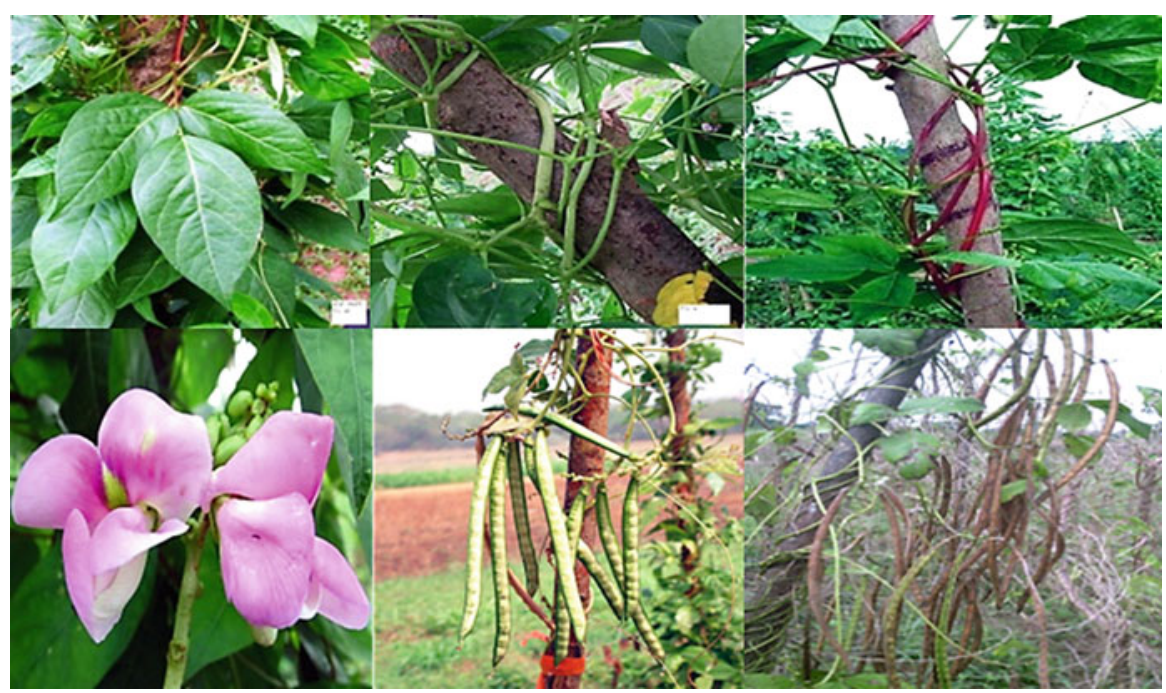

Fig. 3 Growth habit, floral and fruits features of African yam bean. (Photo ${ }^{C}$ Adewale, B. D. and Nnamani, C. V.) 
confirming the common claim that the crop is a tropical African legume. The rich hot spots of S. stenocarpa is found in Chad and Ethiopia in northeast tropical Africa, Kenya, Tanzania and Uganda for east tropical Africa, and in Burundi, Central African Republic and Zaire for west-central tropical Africa. It is also found in West Africa in places like Cote d'Ivoire, Ghana, Guinea, Mali, Niger, Nigeria and Togo while in south tropical Africa it is cultivated in Angola, Malawi, Zambia and Zimbabwe (USDA Agricultural Research Service 2015) (Fig. 4).

In South-east, Nigeria, the plant is diverse in distribution and geographical range thriving more in the derived savanna vegetation zone (Fig. 5).

\section{Nutritional Potentials of African Yam Bean for Climate Change Adaptation}

The seeds and tubers of AYB are highly rich in protein, minerals, and vitamin (Fig. 5). It is a promising source of plant protein for resource poor rural and semi-rural communities. The amino acid (lysine and methionine) has been reported to be higher than those of pigeon pea, cowpea, and bambara groundnut (Uguru and Madukaife 2001). Omeire (2012), noted that the amino acid (g $\left.100^{-1} \mathrm{~g}\right)$ profile of AYB comprised of lysine (6.1), histidine (3.1), arginine (6.5), aspartic acid (9.1), glycine (3.9), alanine (4.1), valine (5.0), and phenylalanine (5.1) (Fig. 5). Its lysipne and methionine contents were similar or better than those of soybean protein (Yetunde et al. 2009) and comparable with whole chicken eggs (Ekpo 2006). The protein profile of the tubers compares favourably with that of other African root crops such as yams and sweet potatoes and has almost two and half times the protein value of cassava tubers (National Research Council 1979; Amoatey et al. 2000; Adewale and Aremu 2013) (Fig. 6).

African yam bean is cultivated for its edible seeds and tubers (Fig. 7), which have sustained indigenous community's livelihoods. A report of its medicinal value was reported in a traditional Igbo settings at Enugu State, Nigeria. The seed is an important ingredient utilized in the topical treatment of stroke, insomnia, diabetics, measles and stress. Extract of mashed AYB, after cooking, is used to induce lactation in mothers after child birth, while the fried seed coat is ground and used in the treatment of stroke (Nnamani et al. 2017). Culturally, it is used traditionally to entertain guests during traditional marriage ceremonies and serves as a famine food when every other crops have failed. Industrially, African yam bean flour is used to fortify conventional wheat flour which is frequently lower in protein content (Nnamani et al. 2017). 


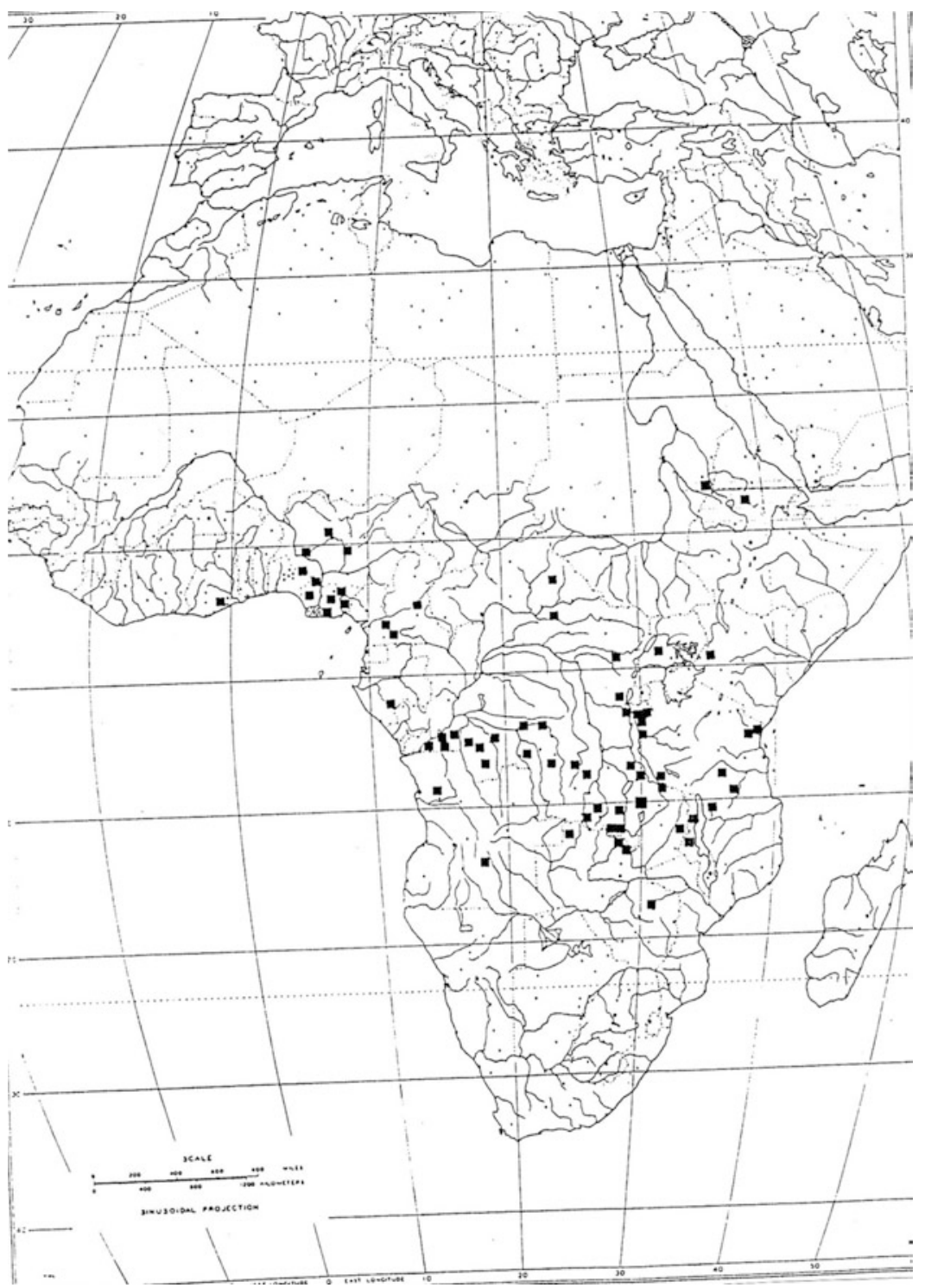

Fig. 4 Center of diversity of African Yam Bean in Africa. (Source: USDA Agricultural Research Service 2015) 


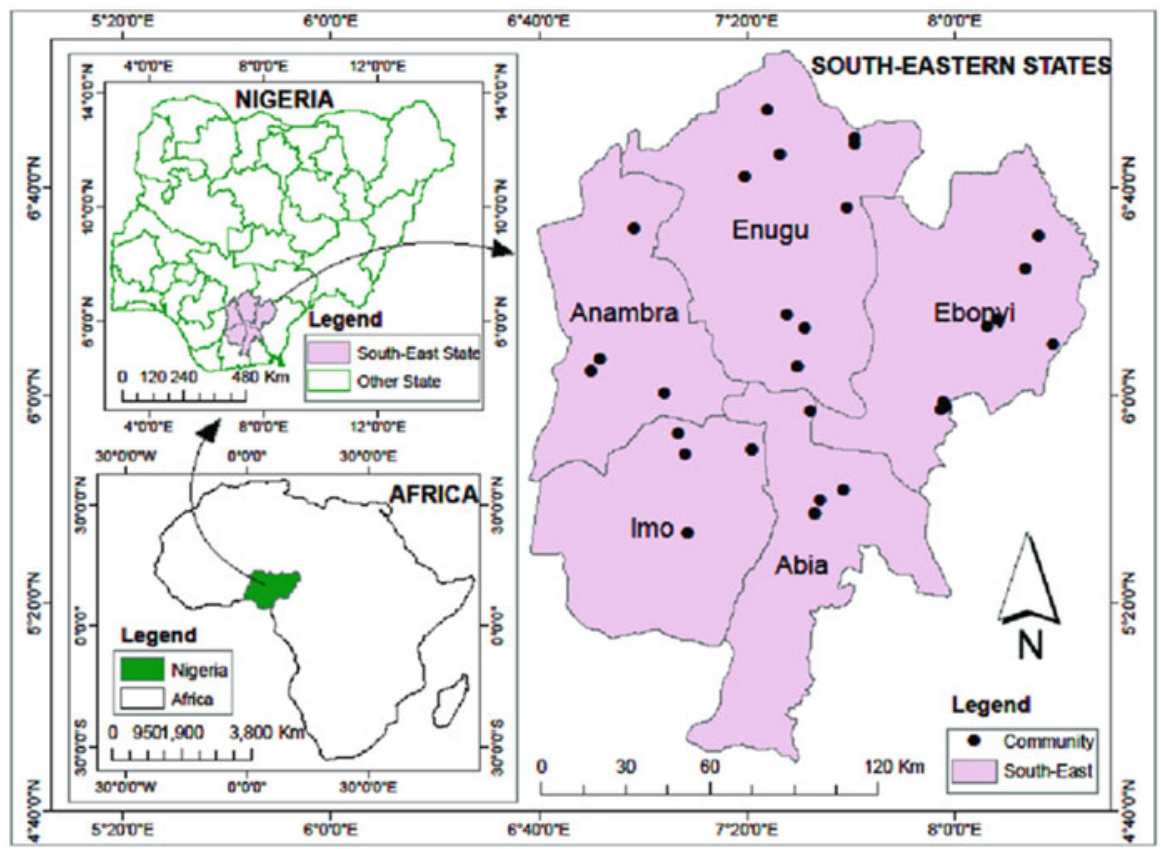

Fig. 5 Geographical distribution of African yam bean in south-east Nigeria. (Source: Nnamani et al. 2017)

\section{Nomenclatural Etymology of African Yam Bean to Climate Change}

Sphenostylis stenocarpa is botanically synonyms in numerous literatures with Sphenostylis ornata A. Chev., Sphenostylis congensis A. Chev., Dolichos stenocarpus Hochst. ex. A. Rich., Sphenostylis katangensis (De Wild.) Harms, Vigna katangensis De Wild., and Vigna ornata Welw. ex. Baker. However, the current acceptable nomenclature is Sphenostylis stenocarpa (Hochst. ex. A. Rich) Harms (Adewale et al. 2012). Keay (1989) reported the followings common names as "Diegemtenguere" (Mali), "Girigiri" (Hausa, West Africa), "Norouko" and/or "Roya" (Sudan). Adewale and Odoh (2013) reported on some of the tribal synonyms of the crop in Nigeria: it is known as "Azama" (Ebonyi, State), "Akidi" or "Azima" or "Okpududu" (Ohafia, Abia State) and "Uzaaku" or "Ijiriji” (Nsukka, Enugu State) in Igbo land; it is "Ewe" (Ijesha, Osun State), "Otiili" (Ekiti, Ekiti State),"Ekulu" (Ipe-Akoko, Ondo State), "Orogodo" (Owo, Ondo State), "Peu” (Ijebu, Ogun State) and "Sunmunu" (Iseyin, Oke-Ogun, Oyo State), Yoruba land. Some other tribal names for AYB in Nigeria are "Ihiehie" (Ishan, Edo State), "Iye" (Estako, LGA, Edo State), "Ahuma" (Tiv, Benue State), "Nsama" (Efik-Ibibio, Akwa Ibom) and Cross River State) (Adewale and Odoh 2013). 


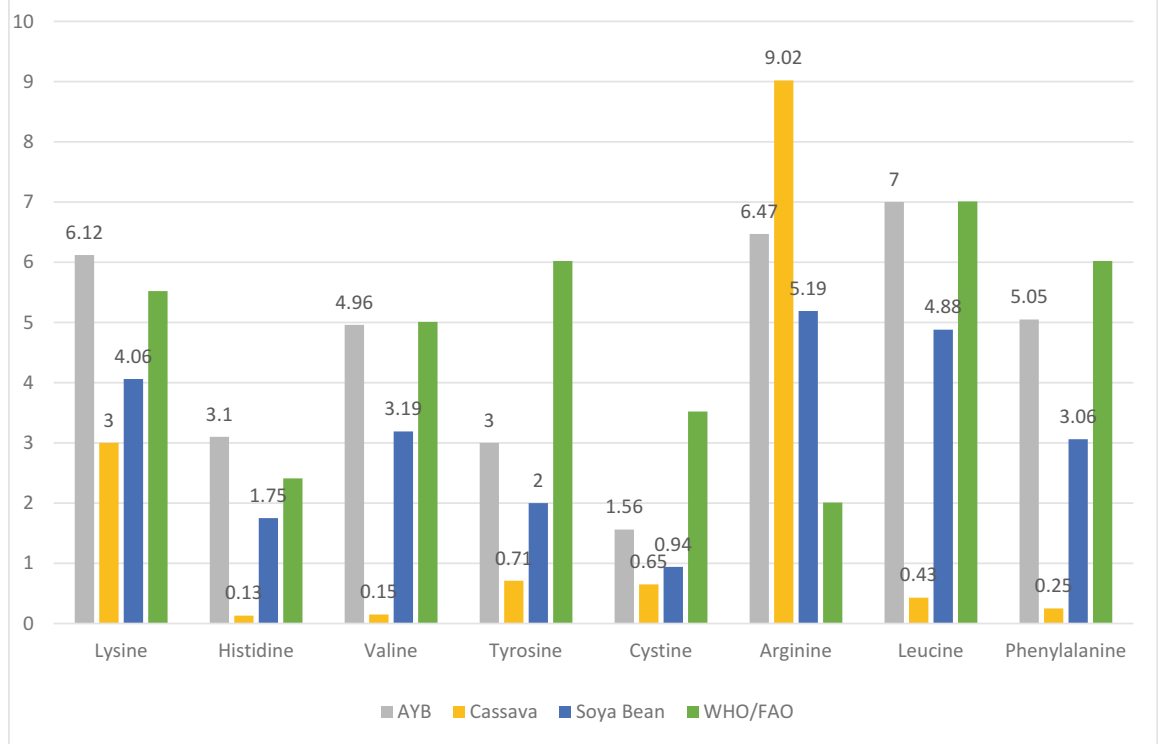

Fig. 6 Amino acid profile of African yam bean compared with other crops and WHO/FAO bench marks. (Source: Omeire 2012)

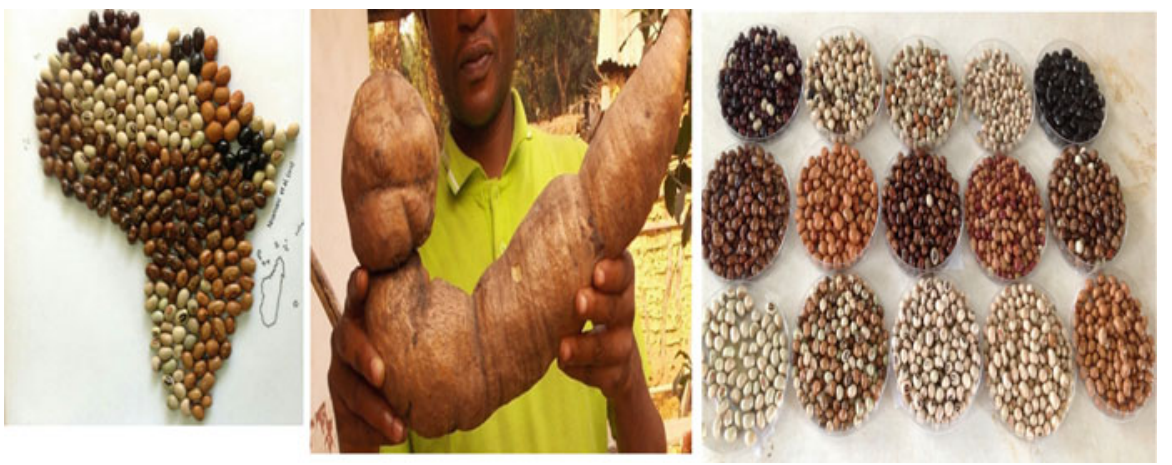

Fig. 7 Seeds and tuber of African yam bean. (Photo (C) Nnamani, C. V. and Adewale, B. D.)

Al Azharia (2006) noted that throughout human history, folk nomenclature has been the underpinning factor for plant selection, improvement and conservation. It was and still is customarily for the local custodians to recognized species which have accomplished high serviceable and cultural values by custodians of such plants worldwide. When folk names given to species it often carries etymological meaning such as healing effects, morphological features, mythical connotations, adaptive strength, mitigating capability and allegorical values (Nnamani et al. 2019). Etymological data showed the AYB had sustained the lives of the local communities for 
ages. Indigenous lingual synonyms for AYB in Nigeria have etymological significances relating to how this crop had interfaced with the livelihood and environmental conditions of the local communities in different scenarios in the past (Table 1). These names often convey relationships to specific plant therapeutic effects, nutritional capacity, morphological features, mythological connotations, and ecological conditions playing out at a particular point in time in their environs (Leyew 2011; Rankoana 2012).

\section{African Yam Bean, the Choice for Climate Change Resilience}

"Neglected and Underutilized species (NUS)" are plant species which are sidelined, ignored or completely underexploited, by researchers, breeders and policy makers. They have great prospects to improve people's livelihoods, guaranteeing food security and self-sufficiency to the users. Their environmental restoration ability are not yet fully appreciated due to their limited competitiveness with fundamental crops in conventional use. Although their potential may not be fully realized at national or international levels, they are of significant importance locally, because of their high adaptation capacity to marginal, complex, and difficult environments contributing significantly to diversification and resilience of agroecosystems (Padulosi et al. 2011).

Shyam et al. (2014) stated that climate modeling is the commonest approach used today for predicting the responses of species to climate change. Species which have resilience biotic characteristics are often informative when used in climate modelling and underutilized plants frequently have an array of stress resistance traits. They are of significant importance locally, highly adaptable to marginal soil, complex and changing environments and agriculturally degraded land. They are hubs contributing meaningfully to diversification and resilience to community agro ecosystems, this is because of their long-standing use with little, or no, conventional breeding improvement. As orphan crops, notwithstanding their intrinsic low-yield potential, they still have the capacity of resisting climate stresses, having been selected and exploited in local climate stress adaptation within the local communities for generations. In this regard, underutilized PGR could contribute to further building of community resilience over the long-term in response to impending climate change adaptation after effective valorization of a PGR's potential (Mabhaudhi et al. 2019).

African yam bean usefulness as a climate smart species for communities to achieve resilience to climate stresses is based on its ability to survive and even thrive (reliable yield annularly) in marginal soils and environments where other crops fail in the absence of often unavailable resources, such as nitrogen fertilization and adequate irrigation. AYB, as a legume, improves soil quality and function through its beneficial effects on soil biological, chemical and physical attributes. Such benefits include enabling improvements in crop N-supply, increasing soil organic matter reserves, stimulating soil microbial diversity and activity, and improvements in soil structure, reducing soil erosion while increasing soil aeration and enhanced soil water-holding capacity. AYB is suitable for wide climatic 
Table 1 Etymology of African yam bean in South-east, Nigerian

\begin{tabular}{|c|c|c|c|c|}
\hline $\begin{array}{l}\text { S/ } \\
\text { no. }\end{array}$ & $\begin{array}{l}\text { Ethnic } \\
\text { group }\end{array}$ & Name & Meaning & Etymological facts \\
\hline 1 & Izzi & Azama & $\begin{array}{l}\text { Feeder of people in } \\
\text { hard times (mitigating } \\
\text { food) }\end{array}$ & $\begin{array}{l}\text { They believed that God had } \\
\text { answered their prayer by giving } \\
\text { them this crop to feed them when } \\
\text { other crops have failed in the land }\end{array}$ \\
\hline 2 & Ezza & Azama & $\begin{array}{l}\text { Healing food for the } \\
\text { people (medicine) }\end{array}$ & $\begin{array}{l}\text { In the past when kwashiorkor } \\
\text { (malnutrition/hidden hunger was } \\
\text { the major problem facing the } \\
\text { people of Ezza, boiling the crop, } \\
\text { eating AYB and the use of water } \\
\text { from the cooked seeds to bath } \\
\text { provides healing }\end{array}$ \\
\hline 3 & Ikwo & Azaaki & $\begin{array}{l}\text { Multiple seed-food } \\
\text { provider (resilient seed) }\end{array}$ & $\begin{array}{l}\text { They named AYB Azaaki because } \\
\text { of the multiple food types it } \\
\text { provides, which help poor farmers } \\
\text { when they cultivate the crop. } \\
\text { They believe that cultivating AYB } \\
\text { is a way of avoiding hunger }\end{array}$ \\
\hline 4 & Ngbo & Azaakuru & $\begin{array}{l}\text { Plant small and harvest } \\
\text { plenty (dominating and } \\
\text { climate-smart crop) }\end{array}$ & $\begin{array}{l}\text { Aza-akuru because, it is a passive } \\
\text { crop but when planted, it will } \\
\text { dominate the whole farm and } \\
\text { yield lots of food types both seed } \\
\text { and the tuberous root. A } \\
\text { dominating crop that God gave to } \\
\text { help poor farmers during famine }\end{array}$ \\
\hline 5 & $\begin{array}{l}\text { Ntezi } \\
\text { and } \\
\text { okpoto }\end{array}$ & Etiti & $\begin{array}{l}\text { "Subduer of hunger" } \\
\text { (the central hungry } \\
\text { killer) }\end{array}$ & $\begin{array}{l}\text { They believed that God has given } \\
\text { them the crop to feed them during } \\
\text { a time of famine. AYB is the only } \\
\text { crop that can feed people even } \\
\text { when the quantity is small }\end{array}$ \\
\hline 6 & Afikpo & Azuma & $\begin{array}{l}\text { Food server } \\
\text { God and medicine }\end{array}$ & $\begin{array}{l}\text { They name this crop Azuma } \\
\text { because of its great feeding } \\
\text { capacity and its ability to stop } \\
\text { some illness, e.g., stomach } \\
\text { disorder. They believed that God } \\
\text { answered their prayer in times } \\
\text { past }\end{array}$ \\
\hline 7 & Ohozara & Aza-ama & $\begin{array}{l}\text { Dominating food crop } \\
\text { God and medicine }\end{array}$ & $\begin{array}{l}\text { Prayer answered by God for the } \\
\text { crop provides food even when } \\
\text { other crops have failed. It yields } \\
\text { great food for the poor. When the } \\
\text { poor cannot cultivate other crops } \\
\text { as a result of environmental } \\
\text { changes }\end{array}$ \\
\hline
\end{tabular}


Table 1 (continued)

\begin{tabular}{|c|c|c|c|c|}
\hline $\begin{array}{l}\text { S/ } \\
\text { no. }\end{array}$ & $\begin{array}{l}\text { Ethnic } \\
\text { group }\end{array}$ & Name & Meaning & Etymological facts \\
\hline 8 & Nkalagu & Azaku & Food helper of the poor & $\begin{array}{l}\text { They called it "Azaku" because of } \\
\text { the role it played during famine in } \\
\text { times past. They believed that } \\
\text { God provided it to help the poor } \\
\text { through its simplicity in } \\
\text { cultivation and survival }\end{array}$ \\
\hline 9 & $\begin{array}{l}\text { Ohafia- } \\
\text { Agba }\end{array}$ & Azama & $\begin{array}{l}\text { Feeder of people } \\
\text { Adaptation to climate } \\
\text { change }\end{array}$ & $\begin{array}{l}\text { They believed that the God of } \\
\text { harvest has provided this crop to } \\
\text { sustain his people when other } \\
\text { crops do not perform very well on } \\
\text { the farm. AYB can compete in } \\
\text { and adapt to many difficult } \\
\text { environments }\end{array}$ \\
\hline 10 & $\begin{array}{l}\text { Agba, } \\
\text { Nkalegu } \\
\text { and } \\
\text { Igboasa }\end{array}$ & Eriwa & $\begin{array}{l}\text { Minor crop that feeds } \\
\text { many people } \\
\text { Gender }\end{array}$ & $\begin{array}{l}\text { It's a women's crop that helps to } \\
\text { sustain the women's little income } \\
\text { when the major crops (the men's } \\
\text { crops like yam, rice and cassava) } \\
\text { are finished in the bans, } \\
\text { particularly after planting. AYB is } \\
\text { usually intercropped with other } \\
\text { crops by women hence it is } \\
\text { termed women's crop }\end{array}$ \\
\hline 11 & $\begin{array}{l}\text { Ezza and } \\
\text { Ikwo }\end{array}$ & Onyiaoduru & $\begin{array}{l}\text { Sustainer and friend of } \\
\text { the farmer } \\
\text { Sustainer }\end{array}$ & $\begin{array}{l}\text { Respondents believe that after } \\
\text { eating AYB, the consumer keeps } \\
\text { drinking water through the day } \\
\text { and it gives sufficient energy to } \\
\text { work without getting exhausted }\end{array}$ \\
\hline 12 & $\begin{array}{l}\text { Ngbo } \\
\text { and Izzi }\end{array}$ & Mgbadumue & $\begin{array}{l}\text { Saving seed } \\
\text { Seed }\end{array}$ & $\begin{array}{l}\text { When labourers are hired to work } \\
\text { on farms. They eat the food in the } \\
\text { morning and it will keep them } \\
\text { active until evening }\end{array}$ \\
\hline
\end{tabular}

Source: Nnamani et al. (2019)

conditions (Anochili 1984; Betsche et al. 2005) and nitrogen fixation (Oganale 2009; Tettey 2014). Ojuederie and Balogun (2019) obtained better tuber production from genotypes in a year with lower rainfall and sunshine hours. This is a display of smart features.

\section{Policy and Conservation African Yam Bean}

Intergovernmental Panel on Climate Change (IPCC 2018) reported the likely consequences of rapid global climatic change on species and their habitats. Such changes could cause a shift in the conservation status of so many species, pushing some towards the red line list of International Union for Conservation of Nature 
(IUCN). African yam bean has not received much conservation attention to date. Currently, much of its germplasm is in the hands of the local custodians as landraces (Nnamani et al. 2018), while the Genetic Resources Centre at the International Institute of Tropical Agriculture (IITA), Ibadan, Nigeria also hold some quantity of AYB germplasm. The disadvantages of poor conservation technology include the limited access to germplasm by researchers, breeders and farmers, the vulnerability of AYB to natural disasters, genetic erosion and loss of crop diversity are there.

Enhancing the potentials of African yam bean by policy via robust innovative approaches for wider utilization through accelerated research, farmer seed exchanges, in-situ and ex-situ conservations, farmers selection, and policy programs such as seed sovereignty will accentuate its adaptation and used as resilient climate smart species for the vulnerable groups in Nigeria to cushion the impact of climate change.

These species may be conserved in-situ or ex-situ for future generations. On-farm (in-situ) techniques have several advantages compared with ex situ conservation, as the former allows for evolution of traits through continued natural and human-driven selections, which will contribute to greater crop adaptation and resilience to abiotic climate stress (Padulosi 2017).

Through the recognition of its promising nutritional potentials, policy could be synchronized in the conservation, promotion, marketing network and utilization of AYB by mainstreaming it into various dietary menus and products to include a range of food products appropriate for a broad range of consumption opportunities. This should include a rebranding of its nomenclature from "poor man's food" to a more widely acceptable range of producers, retailers and consumers. Decision makers could equally support the development of value chains, scale up development collaborations and information sharing of AYB among researchers, conservationists, breeders, extension workers, farmers, farmer organizations, vendors and NGOs.

Finally, there is need for policy to intensify efforts to support research on the conservation of S. stenocarpa through participatory engagement between the species custodians of the species for both in situ and ex situ conservation approaches. Globally the exploitation and development of legumes, which are climate resilient, will provide a significant opportunity for improving human health through integration into food-systems as a replacement, or partial replacement, of current animal sourced proteins. A programmed germplasm conservation approach is needed to collect, characterize, develop and exploit existing diversity in the provision of food, feed, nutritional security and environmental resilience.

\section{Conclusions}

Convincingly, recognizing the potential of AYB as an excellent climate smart species through active food governance policy would initiate novel business opportunities by changing the narrative via: 
(i) Scaling up programs on the use of African yam bean in its various dietary forms and consumptions routes. This could rebrand the nomenclature of the species from "poor man's food" to an added value nomenclature (high protein source).

(ii) Organizing regular retailer food fairs to showcase various dietary menus accruing from AYB will encourage its selection and consumption by the publics.

(iii) Support the development of value chains and market networks for small agribusinesses for priority crops such as AYB.

(iv) Provide credit facilities and farmer/user-friendly technologies to the crop custodians to accelerate production.

(v) Promote the use of AYB through directed awareness campaigns on the nutritional benefits of the crop.

(vi) Exploit the offsetting potential AYB consumption of added value of this nutritious crop against the probable reduction in government health budget associated with alleviating malnutrition and it related conditions.

(vii) Including policy programs that enhance the selection of quality AYB seed available to farmers, with respect to climate resilience.

(viii) AYB will require more attention firstly, research-based, then technological germplasm development and subsequently supporting exploitation policy and markets. This will direct and facilitate appropriate solutions to major constraints for greater AYB cultivation and utilization.

(ix) Scaling up development via policy programs has the prospect of empowering resource poor communities who are predominantly women and the unemployed.

(x) Promote direct and appropriate consumer lead engagement and communication between knowledge acquirers and exploiters to drive AYB germplasm conservation.

(xi) Innovative biotechnological tools should be used to catalyze transformative change in AYB to promote its selection as a major staple food through a broad food product base.

Acknowledgements This work was supported by the CIRCLE Visiting Fellowship Program funded by UK Department for International Development (DfID). Neither the findings none the views expressed, however, necessarily reflects the policies of UK Government.

\section{References}

Adewale BD, Aremu CO (2013) The Nutritional Potentials and Possibilities in African yam bean for Africans. Int J Agric Sci 3(1):8-19

Adewale BD, Odoh NC (2013) A review on genetic resources, diversity and agronomy of African yam bean (Sphenostylis stenocarpa (Hochst. ex. A. Rich.) Harms): a potential future food crop sustainable. Agric Res 2:3-43

Adewale BD, Kehinde OB, Odu BO, Dumet DJ (2008) The potentials of African yam bean (Sphenostylis stenocarpa Hochst. ex. A. Rich) Harms in Nigeria: character distribution and 
genetic diversity. In: Smart J, Haq N (eds) New crops and uses: their role in a rapidly changing world. Centre for underutilized crops. RPM Print \& Design, Chichester, pp 265-276

Adewale BD, Dumet DJ, Vroh-Bi I, Kehinde OB, Ojo DK, Adegbite AE, Franco J (2012) Morphological diversity analysis of African yam bean and prospects for utilization in germplasm conservation and breeding. Genet Res Crop Evolut 59:927-936

Al Azharia J (2006) How Plant Names Reveal Folk Botanical Classification, Trade, Traditional Uses and Routes of Dissemination (II), in Asian Studies. Int J for Asian Stud 7:77-128

Amoatey HM, Klu GYP, Bansa D, Kumaga FK, Aboagye LM, Benett SO, Gamedoagbao DK (2000) African yam bean (Sphenostylis stenocarpa): a neglected crop in Ghana. West Afr J App Ecol 1:53-60

Anochili BC (1984) Tropical agricultural handbook. In: Food crop production. Macmillan Publishers, London, pp 48-50

Betsche T, Azeke M, Buening-Pfaue H, Fretzdorff B (2005) Food safety and security: fermentation as a tool to improve the nutritional value of African yam bean. In: Conference proceeding of the international agricultural research for development, Stuttgart-Hohenheim, October 2005, pp 1-5

Bhat JA, Taiwo S (2015) Plant genetic resources and traditional knowledge in light of recent policy developments. In: Salgotra R, Gupta B (eds) Plant genetic resources and traditional knowledge for food security. Springer, Singapore

Dobermann A, Nelson R (2013) Opportunities and solutions for sustainable food production, background research paper. High-level panel of eminent persons on the post-2015 development agenda. www.post2015hlp.org/wp-content/uploads/2013/05/Doberman-Nelson_Solutions-forSustainable-Food-Production.pdf

Ekpo AS (2006) Changes in amino acid composition of African yam beans (Sphenostylis stenocarpa) and African locust beans (Parkia filicoida) on cooking. Pak J Nutr 5:254-256

Elferink M, Schierhorn F (2016) Global demand for food is rising. Can we meet it?. Harvard Business Review. https://www.researchgate.net/publication/302466629_Global_Demand_for_ Food_Is_Rising_Can_We_Meet_It

FAO (2010) The State of Food Insecurity in the World Addressing food insecurity in protracted crises. Rome. http://www.fao.org/3/a-i1683e.pdf

Food and Agricultural Organization of the United Nations (FAO) (2017) The state of food insecurity in the world 2017. FAO, Rome

Germplasm Resources Information Network (GRIN) (2009) GRIN taxonomy for plants (online)

Grebmer K, Bernstein J, Mukerji K, Patterson F, Wiemers M, Ní Chéilleachair R, Foley C, Gitter S, Ekstrom K, Fritschel H (2019) Global Hunger Index: The Challenge of Hunger and Climate Change. Bonn: Welthungerhilfe; and Dublin: Concern Worldwide

International Plant Genetic Resources Institute (IPGRI) (2003) Annual report. International Plant Genetic Resources Institute (IPGRI), Rome. ISBN 92-9043-591-7

IPCC (2018) Summary for policymakers. In: Masson-Delmotte V, Zhai P, Pörtner HO, Roberts D, Skea J, Shukla PR, Pirani A, Moufouma-Okia W, Péan C, Pidcock R, Connors S, Matthews JBR, Chen Y, Zhou X, Gomis MI, Lonnoy E, Maycock T, Tignor M, Waterfield T (eds) Global warming of $1.5^{\circ} \mathrm{C}$. An IPCC special report on the impacts of global warming of $1.5^{\circ} \mathrm{C}$ above pre-industrial levels and related global greenhouse gas emission pathways, in the context of strengthening the global response to the threat of climate change, sustainable development, and efforts to eradicate poverty. World Meteorological Organization, Geneva, p 32

Keay RWJ (1989) Trees of Nigeria. Clarendon Press/Oxford University Press, New York, p 476

Leyew Z (2011) Wild plant nomenclature and traditional botanical knowledge among three ethnolinguistic groups in northern Ethiopia, Ossrea edn. Ossrea, Addis Abba

Mabhaudhi T, Chimonyo V, Hlahla S (2019) Prospects of orphan crops in climate change. Planta 250:695-708. https://doi.org/10.1007/s00425-019-03129-y

National Research Council (1979) Tropical legumes: resources for the future. National Academy of Sciences, Washington, DC, p 246

Nnamani CV (2015) Innovative stride to zero hunger beyond 2015 in Nigeria. Recent Pat Food Nutr Agric 7:14-21 
Nnamani CV, Ajayi SA, Oselebe HO, Atkinson CJ, Igboabuchi AN, Ezigbo EC (2017) Sphenostylis stenocarpa (ex. A. Rich.) Harms., a fading genetic resource in a changing climate: prerequisite for conservation and sustainability. Plants 6:30. 1-16. https://doi.org/10.3390/plants6030030

Nnamani CV, Ajayi SA, Oselebe HO, Atkinson CJ, Adewale DB, Igwe DO, Akinwale RO (2018) Updates on nutritional diversity in Sphenostylis stenocarpa (Hoechst ex. A. Rich.) Harms., for food security and conservation. Am J Agric Biol Sci 13:38-49. https://oi.org/10.3844/ajabssp. 2018.38.49

Nnamani CV, Atkinson CJ, Ejike JE (2019) Etymology of folk nomenclatures for Sphenostysis stenocarpa (Hoechst ex. A. Rich.) Harms. J Underutil Legum 1(1):135-147

Oganale, D. (2009). Nodulation and nitrogen fixation of African yam beam (Sphenostylis stenocarpa). In: Proceedings of African Crop Science Society conference, Cape Town, 28 September-1 October 2009. Science and technology supporting food security in Africa

Ojuederie OB, Balogun MO (2019) African yam bean (Sphenostylis stenocarpa) tubers for nutritional security. J Underutil Legum 1(1):56-68

Omeire GC (2012) Amino acid profile of raw and extruded blends of African yam bean (Sphenostylis stenocarpa) and cassava flour. Am J Food Nutr 2:65-68

Pachauri RK, Meyer LA (2014) IPCC climate change 2014: synthesis report. Cambridge University Press, Cambridge

Padulosi S (2017) Bring NUS back to the table! GREAT insights Magazine 6(4):21-22. https://hdl. handle.net/10568/89038

Padulosi SN, Heywood V, Hunter D, Jarvis A (2011) Underutilized species and climate change: current status and outlook. In: Yadav SS, Redden RJ, Hatfield JL, Lotze-Campen H, Hall AE (eds) Crop adaptation to climate change. Wiley-Blackwell, Oxford, pp 507-521. https://doi.org/ 10.1002/9780470960929.ch35

Padulosi S, Bergamini N, Lawrence T (2013) On farm conservation of neglected and underutilized species: status, trends and novel approaches to cope with climate change. In: Proceedings of an international conference of biodiversity international, Frankfurt, 14-16 June, 2011. Biodversity International, Rome

Potter D, Doyle JJ (1992) Origin of African yam bean (Sphenostylis stenocarpa, Leguminosae): evidence from morphology, isozymes, chloroplast DNA and linguistics. Econ Bot 46:276-292

Rankoana SA (2012) The use of indigenous knowledge for primary health care among the Northern Sotho in the Limpopo Province. Unpublished Ph.D. thesis, University of Limpopo, Sovenga

Shyam SS, Zachariah PU, Kripa V, Mohan A, Ambrose TV, Manju RS (2014) Vulnerability assessment of coastal fisher households in Kerala: a climate change perspective. Indian J Fish 61:99-104

Tettey A (2014) Nodulation, nitrogen fixation and diversity of the African yam bean rhizobia in four Ghanaian soils. M.Phil. thesis. University of Ghana. http://197.255.68.203/handle/123456789/ 7097

Uguru MI, Madukaife SO (2001) Studies on the variability in agronomic and nutritive characteristics of African yam bean (Sphenostylis stenocarpa Hochst. ex. A. Rich. Harms). Plant Prod Res J 6:10-19

USDA Agricultural Research Service (2015) Germplasm Resources Information Network (GRIN). Ag Data Commons. https://doi.org/10.15482/USDA.ADC/1212393. Accessed 2020-11-29.

World Bank (2014) Turn down the heat: confronting the new climate normal. World Bank, Washington, DC. License: creative commons attribution - non commercial - no derivatives 3.0 IGO (CC BY-NC-ND 3.0 IGO).http://documents.worldbank.org/curated/en/ 317301468242098870/pdf/927040v20WP00O0ull0Report000English.pdf

Yetunde EA, Ukpong SU, Olajumoke L, Ime FA (2009) Nutrient composition and sensory properties of cakes made from wheat and African yam bean flour blends. J Food Technol 7:115-118 
Open Access This chapter is licensed under the terms of the Creative Commons Attribution 4.0 International License (http://creativecommons.org/licenses/by/4.0/), which permits use, sharing, adaptation, distribution and reproduction in any medium or format, as long as you give appropriate credit to the original author(s) and the source, provide a link to the Creative Commons license and indicate if changes were made.

The images or other third party material in this chapter are included in the chapter's Creative Commons license, unless indicated otherwise in a credit line to the material. If material is not included in the chapter's Creative Commons license and your intended use is not permitted by statutory regulation or exceeds the permitted use, you will need to obtain permission directly from the copyright holder.

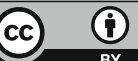

